\title{
Correction to: Ultrasound resistive index, power Doppler, and clinical parameters in established rheumatoid arthritis
}

\author{
Melissa Cláudia Bisi ${ }^{1,2}$ - Aline Defaveri do Prado ${ }^{1,3} \cdot$ Deise Marcela Piovesan $^{1}$. \\ Markus Bredemeier $^{3}$ • Inês Guimarães da Silveira ${ }^{1} \cdot$ José Alexandre Mendonça $^{4}$. \\ Henrique Luiz Staub ${ }^{1}$
}

Published online: 2 November 2017

(C) International League of Associations for Rheumatology (ILAR) 2017

\section{Correction to: Clin Rheumatol (2017) 36:947-951}

https://doi.org/10.1007/s10067-016-3507-3

The original version of this article, unfortunately, contained an error.

One of the author's name on this article was incorrectly spelled as "José Alexandre de Mendonça". The correct spelling is "José Alexandre Mendonça" and is now presented correctly in this article.

The online version of the original article can be found at https://doi.org/ 10.1007/s10067-016-3507-3

Melissa Cláudia Bisi

melissabisi@gmail.com

1 Rheumatology Department, Universidade Pontifícia Católica do Rio Grande do Sul (PUCRS), Porto Alegre, RS, Brazil

2 Rheumatology Department, São Lucas Hospital da PUCRS, Av. Ipiranga 6690, sala 220, Porto Alegre, RS 90480-002, Brazil

3 Rheumatology Service, Hospital Nossa Senhora da Conceição, Grupo Hospitalar Conceição (GHC), Porto Alegre, RS, Brazil

4 Rheumatology Department, Universidade Pontifícia Católica de Campinas (PUCCAMP), Campinas, SP, Brazil 